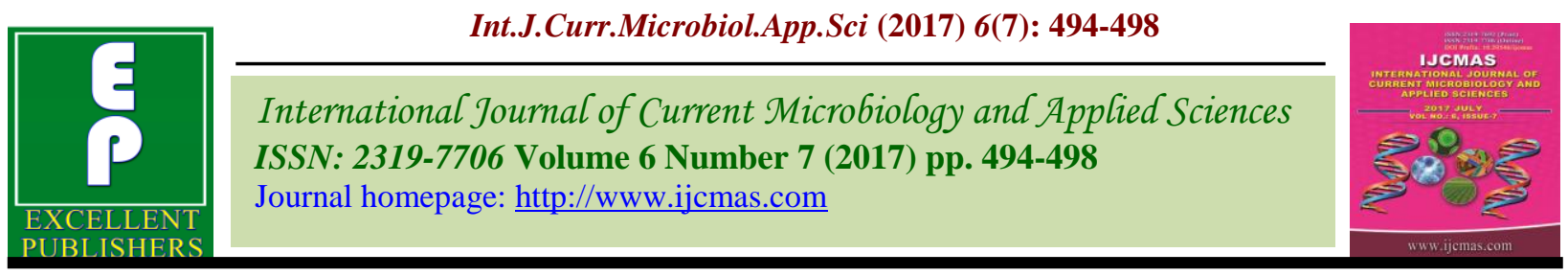

Original Research Article

https://doi.org/10.20546/ijcmas.2017.607.059

\title{
Performance of Ginger (Zingiber officinale Rosc) Varieties under Shade Net Condition of Costal Andhra Pradesh
}

\author{
M. Surendra Babu*, B. Prasanna Kumar, D.V. Swami, K. Uma Krishna and N. Emmanuel \\ College of Horticulture, Venkataramannagudem, West Godavari (D. t) 534101, \\ Andhra Pradesh, India \\ *Corresponding author
}

\begin{tabular}{|c|c|}
\hline & A B S T R A C T \\
\hline & \multirow{7}{*}{$\begin{array}{l}\text { The experiment was taken up to elicit the information on performance of different ginger } \\
\text { (Zingiber officinale Rosc.) varieties under shade net condition. Ten varieties of ginger } \\
\text { were evaluated in RBD with three replications during kharif season of } 2015-16 \text { at } \\
\text { Horticultural College and Research Institute, Dr. Y. S. R. H. U, Venkataramannagudem, } \\
\text { West Godavari district, Andhra Pradesh. The growth performance of ten varieties indicated } \\
\text { significant variation at all the stages of crop growth under shade net condition. Among } \\
\text { the vegetative characters studied, the growth parameters like maximum plant height } \\
(89.83 \mathrm{~cm}) \text {, number of tillers per plant ( } 28.56) \text {, number of leaves per plant }(245.16) \text {, leaf } \\
\text { area per plant }\left(49.39 \mathrm{~cm}^{2}\right) \text {, leaf area index (10.27) were recorded in the variety } \\
\text { Suprabha at } 30,60,90,120,150 \text { and } 180 \text { days after planting. The variety Suprabha } \\
\text { recorded the highest fresh rhizome yield per hectare }\left(32.02 \mathrm{t}^{-1}\right) \text { followed by Himachal } \\
\left.\text { (30.53 tha }{ }^{-1}\right) \text {, Pundibari }\left(29.92 \mathrm{t} \text { ha }{ }^{-1}\right) \text { and Jalsingapara local }\left(27.61 \mathrm{t}^{-1}\right) \text {. It concluded } \\
\text { that the ginger varieties Suprabha, Himachal, Pundibari and Jalsingapara local showed } \\
\text { better performance with respect to growth and yield parameters and these were found to } \\
\text { be suitable for cultivation under shade net condition in Andhra Pradesh. }\end{array}$} \\
\hline Keywords & \\
\hline Ginger, Kharif, & \\
\hline $\begin{array}{l}\text { Varieties and } \\
\text { Horticulture }\end{array}$ & \\
\hline Article Info & \\
\hline $\begin{array}{l}\text { Accepted: } \\
\text { 04 June } 2017 \\
\text { Available Online: } \\
\text { 10 July } 2017\end{array}$ & \\
\hline & \\
\hline
\end{tabular}

\section{Introduction}

Ginger is one of the most important and ancient spice crops in India. It belongs to the family Zingiberaceae. It is a tropical and subtropical perennial herb with underground branching stem called rhizomes. It is native of South East Asia. India is largest producer in the world. Ginger plays an important role in earning foreign exchange for the country. An annual production of $6.55 \mathrm{~L}$ tones in an area of about $1.33 \mathrm{~L}$ hectares in India, contributing approximately $65 \%$ of the world production. Ginger production share among the spices in India is $11.89 \%$ (NHB Database 2014-15). Ginger is grown as an intercrop in coconut and areca nut plantations in the states of
Kerala, Meghalaya, Orissa, and West Bengal and to some extent in Karnataka as well as pure crop in states of Andhra Pradesh, Tamil Nadu. Its cultivation is fast increasing as a pure crop particularly in these states because of better profitability and high productivity can be expected by providing the favorable conditions and better management. Very limited scientific information is available on varietal evaluation of ginger under shade net condition under local agro-climatic condition though the farmers are using their own varieties based on the availability during the season irrespective of suitability for the area under normal open cultivation of the crop. 
Hence, the evaluation of different ginger varieties for their high yielding for a particular agro-ecosystem under shade net condition is of paramount importance to the growers to increase their productivity under controlled conditions. In the present investigation an attempt has been made to find out the performance of different varieties under local agro-climatic zone for their suitability and also to mitigate adverse condition through shade net cultivation and to find out a suitable variety by its performance under shade net condition for the coastal region of Andhra Pradesh.

\section{Materials and Methods}

Ten varieties of ginger varieties viz., Maran, Mahima, Regodi, Zaherabad local, Suprabha, Nadia, Pundibari, Jalsingapara local, Himachal, Narsipatnam local. The experimental site was located in the College farm of Horticultural College and Research Institute, Venkataramannagudem, West Godavari district, Andhra Pradesh. The experiment was laid out in a Randomized Block Design with 3 replications in plot size $2.0 \times 2.0 \mathrm{~m}^{2}$ at the spacing of $35.0 \mathrm{~cm} \times 25.0$ $\mathrm{cm}$. The soil was red sandy loam with good drainage and moderate water holding capacity. The physical composition of the soil was sand $70 \%$, silt $20 \%$ and clay $10 \%$. The soil $\mathrm{P}^{\mathrm{H}}$ of 6.57 , E.C. of $0.3 \mathrm{~d} \mathrm{Sm}^{-1}$, available nitrogen of $186 \mathrm{~kg} \mathrm{ha}^{-1}$, available phosphorus of $32.5 \mathrm{~kg} \mathrm{ha}^{-1}$, available potassium of $215 \mathrm{~kg}$ $h a^{-1}$ and the available organic carbon of $0.34 \%$ was estimated in the experimental area. The field was prepared before the planting and after field preparation, the planting was done in the last week of May, and fertilizers were applied as per recommendations. Five plants/ treatment/ replication were selected at random and studied for growth characters. To crop was harvested after eight months and the data was recorded.

\section{Results and Discussion}

\section{Growth characters}

Ten ginger varieties were evaluated for variation in plant height, number of tillers, number of leaves per plant, leaf area and leaf area index (Table 1) Number of finger rhizomes, Number of primary rhizomes, Number of secondary rhizomes, Weight of primary rhizomes, Weight of secondary rhizomes, rhizome yield per plant, and rhizome yield per ha (Table 2).

The variety Suprabha recorded the highest plant height $(89.83 \mathrm{~cm})$ followed by Himachal $(84.63 \mathrm{~cm})$, Pundibari $(82.56 \mathrm{~cm})$ and Jalsingapara local $(82.06 \mathrm{~cm})$ and was on par with each other and the lowest plant height $(72.56 \mathrm{~cm})$ was recorded in the variety Maran. This might be due to genetic constitution of the varieties which were influenced by controlled climate under shade net condition because of low light intensity (Bhuiyan et. al 2012). The variety Suprabha recorded the highest number of tillers per plant (28.56) followed by varieties Himachal (24.33) which were on par with each other and the lowest number of tillers per plant (13.46) was recorded in the variety Nadia. This might be due to genetic constitution of the varieties and genotypic potential and availability of nutrients in the soil, which were influenced by low light intensity and high relative humidity condition under shade net situation (Lakshmi and Umajyothi, 2014).

The variety Suprabha recorded the highest number of leaves (245.16) was recorded followed by varieties Himachal (241.83) which were on par with each other and the lowest number of leaves per plant (166.56) in the variety Nadia. This might be due to genetic constitution of the varieties and genotypic potential of the cultivars. 
Table.1 Performance of ginger varieties for growth attributes after 180 days of planting (DAP= Days after planting)

\begin{tabular}{|c|c|c|c|c|c|}
\hline \multirow[t]{2}{*}{ Treatments } & $\begin{array}{c}\text { Plant height } \\
(\mathrm{cm})\end{array}$ & No. of tillers/plant & No. of leaves/plant & Leaf area $\left(\mathrm{cm}^{2}\right)$ & Leaf area index \\
\hline & \multicolumn{5}{|c|}{ at 180 days after planting } \\
\hline $\mathrm{V}_{1}$-Maran & 72.56 & 16.40 & 187.70 & 22.63 & 4.84 \\
\hline $\mathrm{V}_{2}$-Mahima & 80.46 & 20.13 & 190.53 & 23.85 & 5.18 \\
\hline $\mathrm{V}_{3}$-Regodi & 78.43 & 18.50 & 202.76 & 24.69 & 5.71 \\
\hline $\mathrm{V}_{4}$-Zahearabad local & 73.53 & 22.50 & 205.66 & 29.45 & 6.95 \\
\hline $\mathrm{V}_{5}$-Suprabha & 89.83 & 28.56 & 245.16 & 32.47 & 9.09 \\
\hline $\mathrm{V}_{6}-\mathrm{Nadia}$ & 73.03 & 13.46 & 166.56 & 23.71 & 4.54 \\
\hline $\mathrm{V}_{7}$-Pundibari & 82.56 & 23.00 & 215.13 & 28.16 & 6.91 \\
\hline $\mathrm{V}_{8}$-Jalsingapara local & 82.06 & 16.03 & 177.03 & 27.25 & 5.51 \\
\hline $\mathrm{V}_{9}$-Himachal & 84.63 & 24.33 & 241.83 & 29.88 & 8.26 \\
\hline $\mathrm{V}_{10}$-Narsipatnam local & 79.10 & 19.76 & 199.56 & 26.07 & 5.95 \\
\hline $\mathrm{SE}(\mathbf{m}) \pm$ & 2.76 & 1.51 & 4.53 & 2.10 & 0.55 \\
\hline CD at $5 \%$ & 8.27 & 4.53 & 13.56 & $\mathbf{N S}$ & 1.64 \\
\hline CV\% & 6.01 & 12.93 & 3.86 & 13.58 & 15.14 \\
\hline
\end{tabular}

Table.2 Performance of ginger varieties for yield attributes

\begin{tabular}{|c|c|c|c|c|c|c|c|}
\hline Treatments & $\begin{array}{l}\text { No. of finger } \\
\text { rhizomes }\end{array}$ & $\begin{array}{c}\text { No. of } \\
\text { primary } \\
\text { rhizomes }\end{array}$ & $\begin{array}{c}\text { No. of } \\
\text { secondary } \\
\text { rhizomes }\end{array}$ & $\begin{array}{l}\text { Weight of } \\
\text { primary } \\
\text { rhizomes } \\
\text { (g) }\end{array}$ & $\begin{array}{l}\text { Weight of } \\
\text { secondary } \\
\text { rhizomes } \\
\text { (g) }\end{array}$ & $\begin{array}{c}\text { Rhizome } \\
\text { yield per } \\
\text { plant } \\
\text { (kg) }\end{array}$ & $\begin{array}{c}\text { Rhizome } \\
\text { yield per ha } \\
\text { (T) }\end{array}$ \\
\hline $\mathrm{V}_{1}$-Maran & 16.53 & 4.06 & 12.80 & 90 & 123 & 213.00 & 22.36 \\
\hline $\mathrm{V}_{2}$-Mahima & 19.13 & 4.66 & 13.46 & 97.14 & 134.86 & 232.00 & 24.36 \\
\hline $\mathrm{V}_{3}$-Regodi & 21.21 & 5.26 & 16.73 & 104.32 & 139.67 & 244.00 & 25.62 \\
\hline $\mathrm{V}_{4}$-Zahearabad local & 21.54 & 5.43 & 17.60 & 103.45 & 146.54 & 250.00 & 26.25 \\
\hline $\mathrm{V}_{5}$-Suprabha & 25.40 & 8.39 & 21.66 & 121.62 & 183.38 & 305.00 & 32.02 \\
\hline $\mathrm{V}_{6}$-Nadia & 16.42 & 3.96 & 11.93 & 82.12 & 112.87 & 195.00 & 20.47 \\
\hline $\mathrm{V}_{7}$-Pundibari & 22.54 & 6.68 & 19.13 & 106.46 & 178.53 & 285.00 & 29.92 \\
\hline $\mathrm{V}_{8^{-}}$Jalsingapara local & 17.66 & 4.26 & 13.40 & 101.88 & 161.11 & 263.00 & 27.61 \\
\hline $\mathrm{V}_{9}$-Himachal & 23.23 & 7.49 & 20.25 & 110.64 & 180.35 & 291.00 & 30.53 \\
\hline $\mathrm{V}_{10}$-Narsipatnam local & 17.40 & 5.18 & 12.79 & 98.74 & 122.25 & 221.00 & 23.20 \\
\hline SE (m) \pm & 0.76 & 0.25 & 0.70 & 3.01 & 4.72 & 5.88 & 0.51 \\
\hline CD at $5 \%$ & 2.30 & 0.75 & 2.12 & 9.02 & 14.15 & 17.61 & $\mathbf{1 . 5 3}$ \\
\hline CV\% & 6.61 & 7.82 & 7.67 & 5.13 & 5.52 & 4.07 & 3.39 \\
\hline
\end{tabular}


It appears that relatively low temperatures and combine with low light intensity contributes to development of more chlorophyll in ginger plants grown in shade leading to higher number of leaves (Vastrad et. al.2006). The variety Suprabha highest leaf area per plant $\left(32.47 \mathrm{~cm}^{2}\right)$ was recorded whereas, the lowest leaf area per plant $\left(22.88 \mathrm{~cm}^{2}\right)$ in the variety Maran. It might be due to the differences in leaf length and width which was influenced by genetic makeup of the varieties and also due to environmental condition in the shade net. The ginger requires a day temperature of $28-35^{\circ} \mathrm{C}$ and high relative humidity throughout the crop period for increased leaf area in ginger (Shetty et al., 2015).

The variety Suprabha highest leaf area index per plant (9.09) was recorded followed by varieties Himachal (8.26) which were on par with each other and the lowest leaf area index per plant (4.54) in the variety Nadia. The increased leaf area index from initial day after planting to at120 DAP is due to more number of tillers and number of leaves per plant which covered the ground area by leaves and high humidity under low light intensity condition under shade. However, the decreased trend from 120 DAP to 180 DAP is might be due to rapid vegetative growth stimulated and increased sink in terms of rhizome formulation might have decreased leaf area index in ginger in shade net condition (Siddalingayya et al., 2014).

\section{Rhizome characters}

The variety Suprabha recorded the highest number of finger rhizomes per plant (25.40) followed by Himachal (23.23) which were on par with each other and the variety Nadia recorded the lowest number of finger rhizomes per plant (16.42). The variety Suprabha was recorded the highest number of primary rhizomes per plant (8.39) followed by Himachal (7.49) and the variety Nadia was recorded the lowest number of primary rhizomes per plant (3.96). The variety Suprabha was recorded the highest number of secondary rhizomes per plant (21.66) followed by variety Himachal (20.25) and the variety Nadia was recorded the lowest number of secondary rhizomes per plant (11.93). The variety Suprabha was recorded the highest fresh weight of primary rhizomes per plant (121.62 g) followed by variety Himachal (110.64 g) and the variety Nadia was recorded the lowest fresh weight of primary rhizomes per plant (82.12 g).

The highest fresh weight of secondary rhizomes per plant (183.38 g) was recorded in the variety Suprabha followed by Himachal (180.35 g) and Pundibari (178.53 g) which were on par with each other and the lowest fresh weight of secondary rhizomes per plant $(112.87 \mathrm{~g})$ was recorded in the variety Nadia.

The variety Suprabha recorded the highest fresh rhizome yield per plant of $305.0 \mathrm{~g}$ followed by Himachal (291.0 g) and the variety Nadia was recorded the lowest fresh rhizome yield per plant of $195.0 \mathrm{~g}$. The variation in rhizome yield among the varieties is mainly due to variation in number of tillers produced per plant, which is genetically controlled characters might be due to low temperature with low light intensity contributed to the development of more chlorophyll in ginger grown under shade, which are resulted in optimum bio-mass increased crop growth resulted in the highest fresh rhizome yield per plant. The rapid vegetative growth stimulated increased sink in terms of rhizome size and thus increase in fresh rhizome yield per plant. The variety Suprabha recorded the highest fresh rhizome yield per hectare (32.02 $\left.\mathrm{t} \mathrm{ha}^{-1}\right)$ followed by Himachal $\left(30.53 \mathrm{t} \mathrm{ha}^{-1}\right)$ and the variety Nadia was recorded the lowest fresh rhizome yield per hectare $\left(20.47 \mathrm{t} \mathrm{ha}^{-1}\right)$. The yield of fresh rhizome is the inherent capacity of the variety 
to put forth better growth in terms of leaf area and no of leaves, no of tillers, plant height and leaf area index of the plant and better growth and production of yield attributes like weight of primary and secondary rhizomes, no of finger rhizomes, no of primary and secondary rhizomes. It can be concluded that the yield of a variety is dependent on vigour of the plant and other plant characters (Siddalingayya et al., 20

In conclusion, the present investigation concluded that varieties Suprabha (32.02 $\left.\mathrm{t} \mathrm{ha}^{-1}\right)$, followed by Himachal (30.53 $\left.\mathrm{t} \mathrm{ha}^{-1}\right)$, Pundibari and Jalsingapara local showed significant performance with respect to growth and yield parameters and found suitable varieties for cultivation of ginger under shade net condition of costal Andhra Pradesh.

\section{References}

Bhuiyan, M.R., Santanu Roy, Sharma P. C. D, Rashid M.H.A, Bala, P.2012 Impact of multi-storeyed agro-forestry systems on growth and yield of turmeric and ginger at Mymensingh, Bangladesh. Sci J. Crop Prod. 1:19-23.
NHB. 2014. Indian Horticulture Database2014 National Horticulture Board, Gurgon, Govt. of India. www.nhb.gov.in.

Lakshmi, R., and Umajyothi, K. 2014 Evaluation of ginger (Zingiber officinale Rosc.) varieties in high altitude and tribal zone of Srikakulam district of Andhra Pradesh. J. Spices Aromat. Crops. 23:258-261.

Shetty, G. R., Narode, K, Venkatesha, J. 2015 Performance of Ginger (Zingiber Officinale Rosc.) Varieties under Hill Zone of Karnataka. Environ. Ecol. 33:1196-2000.

Salimath, S, Venkatesha, J, Kulkarni, S, \& Shetty, R.G. 2014 Evaluation of turmeric (Curcuma Longa L.) cultivars for growth and yield in southern dry zone of Karnataka. Adv. res. J. crop Improv, 5:162-165.

Vastrad, N.V, Hegde, R.V, and Girtammanavar, V.A. 2006 Effect of light intensity and vermicompost and yield of ginger. Karnataka J. Agric. Sci., 19: 941-945.

\section{How to cite this article:}

Surendra Babu, M.B. Prasanna Kumar, D.V. Swami, K. Uma Krishna and Emmanuel, N. 2017. Performance of Ginger (Zingiber officinale Rosc) Varieties under Shade Net Condition of Costal Andhra Pradesh. Int.J.Curr.Microbiol.App.Sci. 6(7): 494-498. doi: https://doi.org/10.20546/ijcmas.2017.607.059 